\title{
What Is Sexual Orientation All About? Explaining an Evolutionary Paradox
}

\author{
Brad Bowins ${ }^{1}$ \\ ${ }^{1}$ MD, F.R.C.P. (C), Centre for Theoretical Research in Psychiatry \& Clinical Psychology, Toronto, Ontario, Canada. \\ Correspondence: brad.bowins@bellnet.ca Brad Bowins, 2200 Yonge Street, Suite 1700, Toronto, Ontario, Canada, M4S \\ 2C6
}

Received: January 16, 2015

Accepted: February 2, 2015

Available online: February 25, 2015

doi:10.11114/ijsss.v3i2.698

URL: http://dx.doi.org/10.11114/ijsss.v3i2.698

\begin{abstract}
Numerous psychological, biological, and evolutionary theories have been proposed to explain sexual orientation. For a theory to be valid it must account for the evolutionary or Darwinian paradox of how homosexual behavior seemingly blocking evolutionary fitness could have evolved. Typically it is only evolutionary based theories that attempt to address this issue. All theories proposed to date have limitations, a major one being that they tend to be specific for male or female sexual orientation. A model for sexual orientation is proposed that both explains the evolutionary paradox of homosexuality and accounts for male and female sexual orientation. The model departs from others by taking the approach that homosexuality and heterosexuality only represent descriptions of underlying natural occurrences. Four interactive components consisting of homoerotic and heteroerotic dimensions, activation/deactivation of these dimensions, erotic fantasy, and social construction comprise the model. Homoerotic and heteroerotic behaviors organized on separate dimensions represent natural occurrences. A completely novel process-activation and deactivation of these dimensions-is proposed to explain various manifestations of sexual orientation. Erotic fantasy provides an additional layer to sexuality beyond physical behavior and serves to activate sexual orientation dimensions, while social construction tends to deactivate inconsistent expressions. The evolutionary paradox only arises when behaviors are remade into identities via social construction, and heterosexual behavior inconsistent with a homosexual identity is deactivated.
\end{abstract}

Keywords: Sexual orientation, homoerotic, heteroerotic, homosexual, heterosexual, erotic fantasy, social construction

\section{Introduction}

The current paper presents a comprehensive model of human sexual orientation. Prior to the presentation of this model animal homosexuality will be briefly examined and existing theories reviewed. Homosexual behavior is clearly present in many species including insects, reptiles, fish, birds, mammals, and primates (Bagemihl, 1999; Davies, 1991; Denneston, 1980; de Waal, 1982; Dunkle, 1991; Goodall, 1965; Kirsch \& Rodman, 1982; Poiani, 2010; Vasey, 1995; Weinrich, 1982; West, 1977). In primates it has been observed and studied in many species such as Japanese macaques (Mehlman, \& Chapais, 1988), stumptail macaques (Mitchell, 1979), rhesus monkeys (Mitchell, 1979), white-handed gibbons (Edwards \& Todd, 1991), as well as great apes including chimpanzees, bonobos, and mountain gorillas (de Waal, 1982; de Waal \& Lansing, 1997; Edwards \& Todd, 1991; Goodall, 1965; Taub, 1990; Wrangham, 1986; Yamagiwa, 1987). However, strict homosexuality is rarely observed, the only known example being a small percentage (up to $8 \%$ ) of domesticated rams (Bagemihl, 1999). What has both fascinated and puzzled researchers is how behavior that apparently blocks reproductive success could have evolved — the "evolutionary or Darwinian paradox."

Numerous explanations of a psychological, biological, and evolutionary nature have been proposed to explain homosexuality most focused on male homosexuality, and relatively few addressing the evolutionary paradox. Psychological explanations derived from psychoanalytic theory see homosexuality as being due to failed identification with the same-sex parent and excessive identification with the other-sex parent, resulting in the person adopting other-sex characteristics (Bieber et al, 1962; Braaten \& Darling, 1965; Evans, 1969; Freud, 1905/1962; O'Connor, 1964). This theory is based on the notion that other-sex gender behavior leads to homosexuality (Bieber et al, 1962; Freud, 1905/1962). However, there is no apparent link between non-gender conforming behavior and homosexuality (Bell et al, 1981; Larson, 1981; Storms, 1980). Consequently, research does not support faulty identification with the same sex parent as playing any significant role in sexual orientation (Bell et al, 1981). My own experience as a 
psychiatrist treating numerous gay individuals for a variety of psychiatric problems, and also issues pertaining to sexual orientation, supports first, that there is little association between non-gender conforming behavior and sexual orientation, and second, that faulty identification with the same-sex parent is rarely an issue.

Biological explanations of homosexuality have focused on altered brain development with the hypothalamus being highly implicated (Dorner, 1980; LeVay, 1991; Swaab \& Fliess, 1985). Countering the notion that homosexuality can be reduced to a clear anatomical deviation none of these results have stood up to repeat investigations (Byne et al, 2001; Lasco et al, 2002; Swaab \& Fliess, 1985). An alternative type of biological explanation restricted to male homosexuality, is the maternal immune hypothesis proposing that male specific antibodies increase in the mother with exposure to more male fetuses, accounting for the reported link between having older brothers and homosexuality (Blanchard, 2008). One major limitation of this theory is that most homosexual males lack siblings, have only sisters, or are the oldest of the male siblings. Research, such as by Bearman and Bruckner (2002), fail to support an association between same-sex attraction and number of older siblings, with these authors suggesting that non-representative samples, and/or indirect reports on siblings' sexual orientation are present in studies finding a fraternal birth order effect. As pertains to the maternal immune hypothesis itself, Whitehead (2007) provides evidence demonstrating that the mechanism lacks validity. Of course the theory is also totally unable to explain female homosexuality.

Evolutionary explanations actually address the evolutionary paradox, typically suggesting that although homosexual behavior reduces reproductive success for the bearer, the underlying gene/s enhance the reproductive success of others sharing those genes (Ciani et al, 2008; Hutchinson, 1959; MacIntyre \& Estep, 1993; Wilson, 1978). Wilson (1978) focusing on kin selection indicates that while homosexuality diminishes individual reproductive success, enhanced altruistic behavior directed towards kin sharing the person's genes more than compensates, by facilitating the passage of those genes onto succeeding generations. However, there is no evidence that homosexuals are more altruistic (Small, 1995). Furthermore, amongst animal species homosexual individuals seem to provide more support to their partners than kin (Akers \& Conway, 1979; Parish, 1994; Yamagiwa, 1987). For example, Yamagiwa (1987) studying mountain gorillas, Akers and Conway (1979) reporting on macaque monkeys, and Parish (1994) examining bonobos found that homosexual behavioral pairings provided more resources to the partner than to relatives. Hence, it is safe to say that kin selection does not account for homosexual behavior.

Heterozygous advantage, as expressed by MacIntyre and Estep (1993) and Hutchinson (1959), states that in a mixed form consisting of both a homosexual and heterosexual gene there might be an advantage to homosexuality, such as perhaps greater nurturing behavior in males. A fatal flaw of this theory is that research evidence does not support a simple gene model of sexual orientation (Baron, 1993; Hamer et al, 1993; Rice et al, 1999). Another explanation for the evolutionary paradox is sexual antagonism (Ciani et al, 2008). The theory proposes that although reproductive success of homosexual males suffers, that of female relatives possessing the same genetic material increases (Ciani et al, 2008). There are some major problems with this theory, one being that it can only explain male homosexuality and has nothing to say about female homosexuality. Another problem with the sexual antagonism theory is that is based on assumptions that might not be valid. For example, homosexuality is more common in male relatives on the mother's side than the father's side (Ciani et al, 2008). This implies that genetic transmission of male homosexuality is based on the female. However, Mustanski et al (2008) conducting the first genome wide scan of male homosexuality did not find evidence supporting the "gay gene," as the media dubbed the female linked Xq28 gene found with an earlier (Hamer et al, 1993) genetic linkage study. In addition, Mutanski et al (2008) discovered evidence for both paternal and maternal transmission based on 7q36 (the strongest linkage) and 8p12. It would then seem that sexual antagonism fails to account for male homosexuality, and fails to provide an explanation for female homosexuality.

From a statistical perspective, the "a priori" probability (prior to a study being conducted) of a result being true influences the interpretation of a positive research outcome - If the a priori probability of a result being true is high the outcome is meaningful, but if the a priori probability is low then a positive outcome only measures bias involved in achieving the positive outcome (Ionnides, 2005). This major statistical issue means that most research findings are actually false (Ionnides, 2005). By any reasonable standard, the a prior probability of the fraternal birth order effect and sexual antagonism outcomes being true must be extremely low, rendering these outcomes a measure of bias, such as with sampling. Bearman and Bruckners's (2002) failure to find any association between same-sex attraction and number of older siblings supports this conjecture for the fraternal birth order effect.

The proposed hypotheses and theories have very significant limitations, and none adequately accounts for the complexity of human sexual orientation, considering both females and males (Bell et al, 1981; Blackwood, 1985; Dickemann, 1995; Haumann, 1995; Larson, 1981; Muscarella, 2000; Rahman, 2005; Small, 1995; Storms, 1980; Whitehead, 2007). While it is possible that completely different mechanisms account for female and male sexual orientation, it is likely that at least at a core level, the mechanism accounting for sexual orientation applies to both females and males, based upon the most parsimonious explanation usually being the most accurate. In addition, no 
theory fully accounts for the evolutionary paradox of homosexuality. One interesting characteristic of the explanations discussed is that they all are specific to human homosexual behavior. Considering that such behavior is present in a wide range of species and very well represented amongst primates, it also logically follows that any explanation should help account for homosexuality across various species.

The current paper provides a new model of sexual orientation. Given that nature builds on existing templates, it takes into account animal homosexuality and our hunting-gathering past. A key problem with most existing theories to date is the assumption that sexual orientation categories are true occurrences. Social constructionists accurately point out that this is not the case, but have not come up with a satisfactory comprehensive theory to explain sexual orientation. The operating assumption here is that "homosexuality" and "heterosexuality" are only approximations of what actually transpires, and hence do not capture the essence of sexual orientation. Four components described in separate sections of the paper comprise the proposed model-Sexual orientation dimensions, activation of these dimensions, erotic fantasy, and social construction of sexual orientation. Activation of sexual orientation dimensions is a completely novel component, capable of explaining many interesting and puzzling aspects of sexual orientation behavior, such as the impact of sexual abuse on expressed behavior. The combination of this unique component with the other three, that are described to varying degrees by other theorists, provides a model of human sexual orientation that accounts for both male and female sexual orientation, and explains the evolutionary paradox.

\section{Dimensional Organization of Human Sexual Orientation}

Human sexual behavior has almost certainly evolved from other species, with primates a particularly important model given our close genetic relationship. Hence, it is crucial to examine the functions of homosexual behavior in animals and definitely primates. Interactions with members of the same species can be social or sexual and involve same-sex and other-sex individuals. These interactions are well characterized by the terms homosocial and heterosocial for non-sexual interactions, and homoerotic and heteroerotic for sexual interactions (Muscarella, 1999, 2000). The terms heterosexual and homosexual carry certain preconceived notions that can bias behavioral interpretations, and hence heteroerotic and homoerotic will be used. Some of the specific functions proposed for homoerotic behavior include proceptivity enhancement (stimulation aiding in heteroerotic sex), receptivity reduction (ensuring that a competitors reproductive energy is wasted facilitating more reproductive opportunities for the initiator of this strategy), ritualized aggression to establish dominance and territory, practice for heteroerotic copulation, tension regulation, reconciliation, and alliance formation (Bagemihl, 1999; deWaal \& Lansing, 1997; Kirsch \& Rodman, 1982; Poiani, 2010; Savage-Rumbaugh, \& Wilkerson, 1978; Van der Dennen, 1995; Vasey, 1995). The first two explanations seem to apply more to cognitively simpler animals such as reptiles (Kirsch \& Rodman, 1982).

Reviewing the literature on 33 primate species demonstrating homoerotic behavior, Vasey (1995) found the strongest support for alliance formation, with substantial support for reconciliation and tension reduction. These three functions actually align in that they promote social solidarity amongst same-sex individuals. Fairbank et al (1977) proposed that alliance formation could provide an adaptive explanation for homosexual behavior. Male yellow baboons mounting and manipulating the other's genitalia form solid alliances against other males (Smuts and Watanabe, 1990). In bonobos female homoerotic behavior allows partners to monopolize food sources and guard against male harassment (Kano, 1992). Homoerotic alliance formation actually appears to enhance survival and reproductive success (Akers \& Conway, 1979; deWaal \& Lansing, 1997; Muscarella, 2000; Small, 1993; Vasey, 1995; Weinrich, 1980). For example, less dominant baboon and rhesus males, who occupy perimeter positions making them more vulnerable to attack, frequently form homoerotic connections not involving dominant-submissive displays (Mori, 1979; Pusey \& Packer, 1987). These relationships help ensure assistance in the event of an attack by a predator or aggression by a more dominate male if an attempt is made to reproduce (Mori, 1979; Pusey \& Packer, 1987; Vasey, 1995). Homoerotic behavior can be quite extensive including mutual embracing, grooming, penis display, touching, mutual masturbation, oral stimulation and mounting (Muscarella, 2000).

More directly demonstrating an enhancement of evolutionary fitness, homoerotic behavior can actually increase access of subordinate males to reproductively active females (Akers \& Conway, 1979; Boelkins \& Wilson, 1972; Hanby et al, 1971; Muscarella, 2000). For example, sexual activity between peripheral males might stimulate increased testosterone that in combination with alliance formation leads to reproductive opportunities. (Muscarella, 2000). Frequently, younger peripheral rhesus monkeys establish homoerotic relationships with more dominant established males, the former gaining social support and elevated dominance status thereby increasing the chances of reproduction (Boelkins \& Wilson, 1972). The dominance status of lower ranking female rhesus monkeys and Japanese macaques has also been observed to be elevated when the individual forms a homoerotic alliance with a more socially dominant female (Akers \& Conway, 1979; Hanby et al, 1971). Elevated status and alliance formation means protection, resources, and reproductive access to the more dominant males of the group presumably possessing better quality genes (Akers $\&$ Conway, 1979; Hanby et al, 1971; Muscarella, 2000). Understanding the functions of homoerotic behavior amongst 
various species, particularly primates, provides the background necessary for understanding human sexual orientation and why there is no evolutionary paradox.

Given the similarity between primates and humans it is reasonable to expect that homoerotic alliance formation, and the related social functions of tension reduction and reconciliation might play a role in human homoerotic behavior. Human homoerotic behavior dates well back into prehistory with 17,000-year old Paleolithic cave paintings showing male erections connected (Ross, 1973). Furthermore, it has been recorded in many cultures past and present (Ford \& Beach, 1951; Greenberg, 1988; Herdt, 1988). Commonly male homosexuality occurs between young men undergoing initiation into adulthood and more dominant older men (Ford \& Beach, 1951; Mackey, 1990). Such unions elevate the status of the younger lower ranking male enabling him to acquire higher status mates for himself and relatives (Boswell, 1980; Cantarella, 1992; Hinsch, 1990; Muscarella, 2000). This occurrence has been observed and recorded in Chinese, Japanese, Roman, and Greek societies (Boswell, 1994; Cantarella, 1992; Hinsch, 1990).

Homoerotic behavior between females is also noted in ancient Chinese, Greek, Roman, and numerous other civilizations (Boswell, 1994; Ford \& Beach, 1951; Greenberg, 1988; Hinsch, 1990), but details are less clear due to the greater emphasis on recording male events (Muscarella, 2000). As with non-human primates human female homoerotic behavior probably aided in alliance formation providing protection, resources, and mating opportunities with higher ranking male members of the society (Muscarella, 2000). A specific form of alliance formation proposed for females is alloparenting, whereby sexual bonding between women aided in care of offspring enhancing evolutionary fitness (Kuhle, 2013). Heteroerotic behavior also likely assisted in alliance formation, tension reduction, and reconciliation, but it can also generate conflict and competition between same-sex individuals-If a young reproductively active individual attempts to establish an alliance with an older other-sex individual this might well be reacted to with aggression from more dominant same-sex individuals. Both homoerotic and heteroerotic behaviors then appear common amongst various animal species and human societies providing distinct benefits, but how are these behaviors organized in relationship to each other?

Nature might conceivably be organized discretely or dimensionally. Responding to the notion that human sexual orientation might be discrete and not continuous, Kinsey et al state in Sexual Behavior in the Human Male (1948), "Males do not represent two discrete populations, heterosexual and homosexual. The world is not divided into sheep and goats. It is a fundamental of taxonomy that nature rarely deals with discrete categories... The living world is a continuum in each and every one of its aspects." Kinsey et al add in Sexual Behavior in the Human Female (1953), "It is a characteristic of the human mind that tries to dichotomize in its classification of phenomena... Sexual behavior is either normal or abnormal, socially acceptable or unacceptable, heterosexual or homosexual; and many persons do not want to believe that there are gradations in these matters from one to the other extreme."

These statements capture how nature and certainly human sexuality is organized in a continuous fashion, while our perception of discrete categories is an illusion arising from a psychological inclination to dichotomize when classifying. Discrete entities are easier to process mentally, accuracy being traded off for simplicity. Natural phenomena tend to be organized continuously, because continuums provide for trait variation necessary for natural selection and evolution (Behrman \& Kirkpatrick, 2011; Brousseau et al, 2013; Chevin \& Lande, 2013; Darwin, 1858). Traits lacking any variation (truly discrete) either persist if selection pressures favor the given characteristics or perish if not favored, an either or scenario. Ample trait variation provided by a continuous organization of forms, allow for the most adaptive variant/s to become more represented in succeeding generations (Behrman \& Kirkpatrick, 2011; Brousseau et al, 2013; Chevin \& Lande, 2013; Darwin, 1858). A formal statement that might be referred to as the "continuum principle" is warranted considering our automatic tendency to apply discreteness to what are almost universally continuous variables - Natural phenomena tend to occur on a continuum, and any instance of hypothesized discreteness requires unassailable proof. In regards to sexual orientation, there is no evidence that it is discrete despite the tendency of people to dichotomize it in terms of heterosexual and homosexual, with several researchers from diverse fields of enquiry proposing that it is organized dimensionally (Friedman, 1988; Kauth, 2000; Kinsey et al, 1948; Kinsey et al, 1953; LeVay, 2012; Money, 1988; Muscarella, 1999; Priebe \& Svedin, 2013; Shively \& DeCecco, 1977; Storms, 1980; Weinrich, 1980, 1982).

While it appears that sexual orientation is dimensional, the question arises as to how many dimensions apply? Although appealing for its simplicity, a single dimension ranging from homosexual to heterosexual, as for example used by Kinsey et al $(1948,1953)$, presents some major conceptual and practical problems (Muscarella, 1999; Shively \& DeCecco, 1977; Storms, 1980). To start, homosexual and heterosexual motivation must represent a tradeoff, with more of one meaning less of the other. Consequently, a bisexual individual is less hetero than a strictly heterosexual orientation and less homo than a fully homosexual orientation. Clearly this is not the case as many bisexuals report urges for both sexes of comparable or greater strength than strict heterosexuals and homosexuals (Shively \& DeCecco, 1977; Storms, 1980). It also implies that strict homosexuals and heterosexuals must have powerful urges towards their 
respective sex of attraction, not accounting for a range of sexual motivation in both groups. Another major problem involves the so-called fourth dimension of sexual preference-Asexuality. According to a single dimension model, asexuals demonstrating very low motivation for either sex are equivalent to bisexuals, an obviously false scenario (Muscarella, 1999; Shively \& De Cecco, 1977; Storms, 1980). On the Kinsey scale asexuals have to be placed off the scale with an X rating, or if on the actual scale placed at the same point as bisexuals (Kinsey et al, 1948).

Klein (1993) proposed a multidimensional model of sexual orientation-Klein Sexual Orientation Grid. The grid incorporates different dimensions at three points in a person's life - past, present, and idealized future. The dimensions consist of sexual attraction, sexual behavior, sexual fantasies, emotional preference, social preference, lifestyle preference, and self-identification, with ratings from 1-7 (other-sex only/heterosexual only to same-sex only/homosexual only). While Klein's grid does provide a rich description of behavior and preferences linked to sexual orientation there are several limitations. One problem being that by trying to provide more dimensions the model ironically might not include enough dimensions, such as age and masculine/feminine behavior. Of even greater significance is that the dimensions proposed appear to be measuring the same construct (Weinrich et al 1993). A factor analytic study by Weinrich et al (1993) using 2 samples found that one factor loaded on all of the grid's 21 components ( 3 for past, present, and idealized future and the 7 dimensions), meaning that they are all measuring the same construct or dimension. A second factor emerged consisting of social and emotional preferences, indicating that these "dimensions" are measuring something other than sexual orientation (Weinrich et al, 1993). A likely reason for these results is that Klein's "dimensions" probably only constitute descriptors of sexual orientation dimensions (and another dimension for social and emotional preferences). For example, sexual attraction, sexual behavior, sexual fantasies, lifestyle preference, and self-identification, might only describe sexual orientation dimensions, and not constitute actual dimensions. Supporting this assertion is the finding by Priebe and Svedin (2013) that different measures of sexual orientation (identity, attraction, and behavior) are significantly associated with each other.

An alternative way of conceptualizing sexual orientation is two separate dimensions of homoerotic and heteroerotic (Shively \& De Cecco 1977; Storms, 1980). According to a two-dimensional model there are both homoerotic and heteroerotic motivations applicable to everyone (Shively \& De Cecco, 1977; Storms, 1980). This conceptualization of human sexual orientation fits much better with the realities of bisexual and asexual orientations. For example, a bisexual person can have robust desires for both same and other-sex partners, comparable in intensity to homosexuals and heterosexuals, respectively, as fits with observations (Shively \& DeCecco, 1977; Storms, 1980). Furthermore, asexual individuals are not placed in the same category as bisexuals or rated off the scale, being accurately characterized by a low or zero standing on both the heteroerotic and homoerotic dimensions. Homosexuals have a lower level of heteroerotic motivation and substantially higher homoerotic motivation, with the reverse pattern for heterosexuals.

Assuming that there are separate homoerotic and heteroerotic dimensions, how might they be structured? One option is the model by Michael Storms (1980) plotting homoerotic and heteroerotic motivations on a chart with horizontal and vertical axes. "Hetero-eroticism" is rated on the horizontal axis from low to high, and "homo-eroticism" is placed on the vertical axis also from low to high. According to this representation, asexuals are low on both motivations, bisexuals are high on both, and heterosexuals and homosexuals high on the motivation consistent with their preference, and low on the one that is inconsistent with their preference. This precise organization is problematic in that it does not readily allow for low ratings other than for asexuals. What about bisexuals with equivalent but fairly low motivation for both sexes, homosexuals with higher but limited motivation for same-sex individuals, and heterosexuals with higher but restricted motivation for other-sex partners? Separate side-by-side homoerotic and heteroerotic dimensions appear to make more sense, with asexuals at the very low end of both, homosexuals having higher same-sex motivation regardless of the precise levels, heterosexuals higher other-sex motivation regardless of the precise levels, and bisexuals with variable but substantial motivation for both sexes.

Separate homoerotic and heteroerotic dimensions mean that humans have the capacity for both, with motivations ranging from potentially zero to very high. The issue of why most people identify with being heterosexual is important to address. While homoerotic behavior apparently can indirectly facilitate reproductive success, heteroerotic behavior does so directly, at least prior to the introduction of birth control strategies. Given the pivotal role of other-sex contact in reproduction it is highly feasible that heteroerotic motivation is higher in most individuals than homoerotic motivation, as represented by placement on each dimension. Consequently, more people identify with being heterosexual.

The presence of homoerotic behavior in a wide range of animal species likely serves as a natural template for the homoerotic dimension, and male-female reproductive behavior provides for the heteroerotic dimension. This two-dimensional organization of sexual orientation also fits well with the notion that both heteroerotic and homoerotic behavior enhance evolutionary fitness. Heteroerotic behavior obviously facilitates reproductive success and can serve the important social functions of alliance formation, tension reduction, and reconciliation, at least in some instances. Homoerotic behavior strongly promotes these social benefits in animals, and certainly in primates including humans, 
with the most significant benefit being alliance formation providing support and protection, access to resources, and enhanced reproductive opportunities often with higher-ranking individuals (Akers \& Conaway, 1979; Boelkins \& Wilson, 1972; Fairbanks et al, 1977; Hanby et al, 1971; Kano, 1992; Mori, 1979; Muscarell, 1999; Muscarella, 2000; Pusey \& Packer, 1987; Small, 1993; Smuts \& Watanabe, 1990; Vasey, 1995; Weinrich, 1980). The implication being that those who have a zero or very low motivation on the homoerotic dimension, might well have been at a disadvantage throughout evolution based on an inability to form fitness enhancing alliances with same-sex members of the group or society. Amongst bonobos an individual who does not form homoerotic alliances is at a distinct disadvantage when it comes to securing important resources including mates (deWaal \& Lansing, 1997).

Considering that the heteroerotic dimension is separate, a solid homoerotic motivation would not have precluded reproduction. In contrast it appears to have enhanced opportunities to capitalize on heteroerotic motivation. This rationale can be extended further in that a very high heteroerotic motivation combined with an extremely low homoerotic motivation could have resulted in ostracism, and hence reduced reproductive opportunities - Individuals with this combination might have sought reproductive opportunities without alliance support incurring the wrath of higher ranking members of the group. Some homoerotic motivation would help ensure sufficient alliance formation reducing the likelihood of fitness diminishing ostracism.

The value of a given level of heteroerotic or homoerotic motivation would probably have varied with social and environmental circumstances during our evolution in a hunting-gathering context. For instance, if few reproductively active females were present and competition for them intense, a higher homoerotic and more moderate level heteroerotic motivation in males might be most adaptive-This combination would foster alliances that could facilitate reproductive opportunities, would provide sufficient motivation to take advantage of these opportunities, but not so much that the male skips alliance formation and prematurely seeks mating opportunities resulting in attacks and ostracism from more dominant males. Conversely, in a setting with many reproductively active females and little competition a higher heteroerotic motivation and lower homoerotic motivation would be more adaptive, because homoerotic alliance formation would not be as important. For females a similar pattern would apply but the emphasis would be on higher quality males for reproduction given limits to reproductive capacity (Barish, 1982; Ellis \& Simmons, 1990; Singer, 1985).

A two dimensional model of sexual orientation then aligns well with both the realities of sexual orientation and the evolutionary fitness benefits of homoerotic and heteroerotic behavior. An important question is whether a person can actually have a zero value of each dimension or just a low value? Arguable to facilitate reproductive success and provide the social benefits derived from a homoerotic motivation there might be non-zero motivations. Zero values do occur with certain forms of mental illness, such as the deficit state of schizophrenia, severe depression, or as an aftermath of sexual abuse (Bemporad, 1991; Bowins, 2004; Mahurin et al, 1998). While debatable it is feasible that complete asexuality represents a symptom of mental illness, and in the absence of such difficulties there are non-zero values on both the homoerotic and heteroerotic dimensions. However, research is required to answer this question. In contrast, it is clear that there is no evolutionary paradox given the benefits of homoerotic behavior including for reproduction, and the simultaneous presence of both homoerotic and heteroerotic motivations. Beyond separate homoerotic and heteroerotic dimensions, activation and deactivation of both represent a crucial component of the proposed model, and one that aligns with how the brain is largely structured on the basis of activation/deactivation.

\section{Activation/Deactivation of Dimensions}

Assuming, based on the prior discussion, that there are separate homoerotic and heteroerotic dimensions, the question arises as to how they are expressed in each individual? As a starting point, it is likely that genetic and early (even prenatal) environmental factors produce a given level of motivation on each dimension that varies between individuals, although research will have to prove this supposition. The dominant motivation is the one most likely to be active and expressed. Hence, if a person has a higher level of motivation on the homoerotic dimension then the person will most likely identify with being homosexual. The non-dominant dimension though can be activated by specific circumstances, including even an opportunity for pleasure, resulting in the expression of an individual's given level of motivation. For example, if an instance arises where alliance formation is adaptive, the presence of a suitable same-sex partner might activate the homoerotic dimension bringing out the individual's level of motivation.

Homoerotic behavior increases in same-sex settings including schools, prisons, and religious institutions such as nunneries (Bell et al, 1981; Diamond, 2006; Maeve, 1999; Money, 1988). Adolescent boys in same-sex boarding schools partake in more homoerotic relationships than those in mixed-sex schools, but do not demonstrate higher rates of homoerotic behavior as adults (Bell et al, 1981; Money, 1988). The same phenomenon at all-female colleges is common being known as "lesbian until graduation" (Diamond, 2006). In prisons women have been found to bond sexually based on the need for friendship and a relationship that is supportive and not hostile (Maeve, 1999). In settings other than 
forced ones such as prisons, this occurrence might partly be explained by selection (homosexual individuals might unconsciously or consciously seek such settings). However, "selection" cannot account for the observed shift to more heteroerotic behavior in other-sex settings (Bell et al, 1981; Diamond, 2006; Maeve, 1999; Money, 1988). A viable alternative explanation is that the same-sex setting activates the homoerotic dimension resulting in its expression, at least when there is significant level of motivation on that dimension. As pertains to the heteroerotic dimension, triggers such as a reproductive opportunity or alliance formation can activate this dimension. The notion that sexual orientation dimensions can be activated or deactivated aligns with research demonstrating that homoerotic behavior can be elicited by circumstances (Easpaig et al, 2014; Iasenza, 2010; Kennedy, 2010; McKenzie, 2010; Pedersen \& Kristiansen, 2008).

The concept of sexual orientation dimension activation/deactivation might help account for some puzzling occurrences. One such occurrence is why identical twins are only $20-50 \%$ concordant for sexual orientation (Bailey \& Pillard, 1991). Aside from early environmental non-shared influences impacting on the level of homoerotic and heteroerotic motivation, it is feasible that alternative dimensions might be preferentially activated in each twin as development proceeds, perhaps as a way of establishing individual identities. This differential activation of sexual orientation dimensions takes the twins down different paths of sexual development helping to distinguish them.

Another puzzling occurrence that can be explained by sexual dimension activation/deactivation is sexual abuse having variable effects on sexual behavior, in some instances seemingly intensifying motivation for individuals of the same sex as the perpetrator, and in other instances reducing it (Bramblett \& Darling, 1997; Brown, 1963; Harrison et al, 2008; McLaughlin et al, 2012). Sexual abuse, and particularly during a vulnerable period of development, can activate the sexual dimension corresponding to the sex of the perpetrator; the homoerotic dimension in the case of same-sex perpetrators and heteroerotic with other-sex perpetrators. Activation of the dimension results in the expression of an individual's given level of motivation in the form of behavior, attraction, fantasy, and perhaps self-identification. This early and often repetitive activation of the given dimension can lead to overly sexualized behavior consistent with the activated dimension, although over-sexualization generally can also occur. Sexualization of behavior is one of the most consistently reported impacts of sexual abuse (Calam et al, 1998; Estes \& Hotte \& Rafman, 1992; Putman, 2003; Tidwell, 2002), and might be more likely to occur when sexual arousal occurs (Hall et al, 1998). Calam et al (1998) followed 144 sexually abused children and adolescents for 2 years post investigation, and found that sexualized behavior increased over this time frame. Research has shown that sexual abuse involving close relatives maximizes sexualization of behavior, apparently due to sexualization of attachment, according to Middleton (2013).

Consistent with how sexual abuse can have variable impacts on expressed sexual orientation (Bramblett \& Darling, 1997; Brown, 1963; Harrison et al, 2008; McLaughlin et al, 2012), deactivation of the corresponding sexual dimension can occur when the event is sufficiently traumatic at the time. Consequently, the person's level of motivation will not be expressed. Hence, a male violently abused by an older male might experience deactivation of the homoerotic dimension, and reject such behavior even if there is a substantial motivation for it. A female aggressively abused by a male likewise might experience deactivation of the heteroerotic dimension, and hence not express this motivation even if her level is quite high. Deactivation of a sexual orientation dimension due to trauma might in some instances increase the likelihood of the alternative dimension being activated, at least in the context of a circumstance that can activate it, although traumatic sexual abuse often diminishes motivation for sexual and interpersonal contact in general. The comment might be raised that sexual abuse is always traumatic, and hence should routinely result in deactivation of the corresponding sexual orientation dimension. However, older individuals who sexually abuse children or adolescents frequently are quite attentive to the needs of those they abuse, and are violent only in a minority of instances, meaning that the abuse is not always traumatic, at least in the immediate context (Murray, 2000). The impact of sexual abuse on expressed sexual orientation should not be construed as abuse causing sexual orientation; instead, the impact is restricted to the expression of an individual's level of homoerotic and heteroerotic motivations via activation/deactivation of these dimensions. Different brain regions are activated in response to sexual stimuli consistent and inconsistent with expressed sexual orientation, in line with how the brain largely operates on the basis of activation/deactivation (Paul et al, 2008), suggesting the possibility of a neural basis for homoerotic and heteroerotic dimension activation/deactivation.

Deactivation of the homoerotic and heteroerotic dimensions can also account for an apparent zero motivation on one or both. This is certainly conceivable in the case of sexual abuse and some forms of mental illness. For example, with severe depression a person loses motivation for many self-sustaining behaviors, and sexual functioning can be non-existent (Bowins, 2004). The deficit state of schizophrenia, consisting of so-called absence symptoms including apathy, amotivation, avolition, anhedonia (absence of pleasure), motor retardation, affective blunting and absence of play and curiosity, can remove most or all sexual motivation in some individuals (Bemporad, 1991; Mahurin et al, 1998). Consequently, in severe variants of depression and schizophrenia, as well as sexual abuse, homoerotic and heteroerotic dimensions can be deactivated.

The concept of sexual orientation dimension activation/deactivation then helps account for the impact of environmental 
and mental health influences on homoerotic and heteroerotic behavior. Certain influences can activate a dimension, such as the presence of a partner for reproduction activating the heteroerotic dimension, or an opportunity for same-sex alliance formation activating the homoerotic dimension. Even strong feelings of love or admiration for a person might activate the corresponding sexual orientation dimension. Deactivation of sexual orientation dimensions can occur with certain forms of mental illness, providing at least a partial explanation for asexuality. The puzzling effect of sexual abuse on later sexual behavior can also be accounted for with more pleasurable contact often producing excessive activation of the dimension consistent with that of the abuser, and painful contact deactivation of the relevant dimension. Greatly influencing activation and deactivation of sexual orientation dimensions is erotic fantasy.

\section{Erotic Fantasy}

Freud (1908/1962) believed that erotic fantasy compensates for repressed sexuality. In contrast to this psychoanalytic perspective research clearly reveals that erotic fantasy is an indicator of healthy sexuality (Crepault \& Coulture, 1980; Kinsey et al, 1948; Kinsey et al, 1953; Leitenburg \& Henning, 1995; Lentz \& Zeiss, 1983). For instance, women who have more erotic fantasies during masturbation experience more frequent orgasms during intercourse (Lentz \& Zeiss, 1983). In line with this finding, Kinsey et al (1953) discovered that some women achieve orgasm just by fantasizing. A high percentage of men $(86 \%)$ and women (69\%) have sexual fantasies during masturbation (Leitenburg \& Henning, 1995). Furthermore, $76 \%$ of men and $70 \%$ of women have sexual fantasies during intercourse (Leitenburg \& Henning, 1995). Examining men's erotic fantasy, Crepault and Coulture (1980) found that men who frequently have sexual fantasies during intercourse tend to be more sexually active generally, with robust erotic fantasies outside of sexual activity, better capacity to control the timing of ejaculation, a more active role in sex, and other indicators of heightened sexuality, such as experimentation with homoerotic behavior. Hence, research evidence indicates that erotic fantasy is an integral component of healthy sexual functioning.

Daryl Bem (1996) emphasized the role of erotic fantasy in sexual orientation, proposing that that biology plays an indirect role in sexual orientation by influencing childhood temperaments that guide a child's preferences for sex-typical or sex-atypical activities and peers. Due to "atypical" preferences the child feels different from other or same-sex peers, the exotic part. The heightened physiological (autonomic) arousal derived from feeling different than same-sex individuals later becomes eroticized to sexual arousal for that same class of peers, a process he refers to as "sexual imprinting." Despite it being a very creative theory and incorporating erotic fantasy, there are major problems with it. For one, many "gay" individuals do not have preferences different than same-sex peers (Larson, 1981). The notion that gay men are effeminate and lesbians are masculine is a stereotype that is not born out by research data (Larson, 1981). Many gay men have very gender typical preferences, as do lesbian women. In many instances of advanced other-sex behavior it is actually a matter of transgender, and not sexual orientation. Second, it is only meaningful within the context of a single erotic dimension from homo to hetero-If both dimensions exist in each person there is no need to explain heterosexual or homosexual orientations in either/or terms.

Erotic fantasy actually plays a much more profound role in sexual orientation than what a theory such as Bem's suggests-Erotic fantasy adds an entire layer of sexuality beyond actual behavior! When we consider sexuality in animals we focus on sexual acts, in part because that is all that is visible, but also due to how animals probably do not engage in erotic fantasy. Perhaps the most intelligent animals, such as dolphins and great apes, might have some fantasy equivalent to that of a 2-3 year old child, but overall the role of erotic fantasy in animals is likely very limited. The evolution of human intelligence amplifies psychological states such as emotional experiences (Bowins, 2004). Human intelligence amplifies sexuality via erotic fantasy (Leitenberg \& Henning, 1995). Erotic fantasy is at least as important to sexuality as actual behavior, meaning that it adds another level or layer to sexual orientation. Anyone doubting the value of erotic fantasy to human sexual orientation must consider this question-If a person engages in erotic fantasy that is exclusively focused on same-sex individuals, but only partakes in sex with other-sex individuals, what sexual orientation do they best fit into? Given the private nature of erotic fantasy there is no censorship or negative influence unless derived from a person's own guilt, hence it tends to be a more accurate indicator of a person's level of homoerotic and heteroerotic motivation (Kinsey et al, 1948; Kinsey et al, 1953; Storms, 1980).

Erotic fantasy also appears to play a role in sexual dimension activation/deactivation. The power of erotic fantasy to activate sexual orientation dimensions is likely crucial in how motivation for one or both appear to be able to increase over time, consistent with the notion of sexuality being a fluid and dynamic process that can vary throughout the life cycle (Eschoffier, 1998; Klein et al, 1985). For example, if a person has a pleasing homoerotic relationship during adolescence erotic fantasy over time about this experience will continuously activate the homoerotic dimension. This activation will increase the likelihood of repeat experiences that in combination with erotic fantasy will intensify homoerotic motivation.

The role of dimension activation/deactivation in accounting for the impact of sexual abuse on subsequent sexual behavior 
can be augmented by sexual fantasy. When a person is sexually abused even in childhood some pleasure can be experienced, perhaps just from the attention being paid to the individual. Older individuals who sexually abuse children or adolescents frequently are quite attentive to the immediate needs of those they abuse and are violent only in a minority of instances (Murray, 2000). Erotic fantasy facilitated by the pleasure and attention component, combined with ongoing activation of the relevant sexual dimension derived from direct contact (homoerotic if same-sex and heteroerotic if other sex), amplifies sexual arousal for the incident. On the other hand, if the abuse was violent, frightening, or damaging, erotic fantasy will often be blocked reinforcing deactivation of the relevant sexual dimension, thereby reducing or eliminating sexual interest. Erotic fantasy, dimensions of sexual orientation, and the activation/deactivation of those dimensions are processes operating largely at the individual level. The fourth and last component of the model, social construction of sexual orientation, takes into account the influence of the larger social group, and demonstrates how social influences can strongly guide the expression and understanding of sexual orientation.

\section{Social Construction}

Homoerotic and heteroerotic dimensions appear to be biologically based due to their beneficial impact on evolutionary fitness. However, the social environment plays a profound role in how sexual orientation is understood or framed, and this social construction influences how homoerotic and heteroerotic behavior is expressed (Focault, 1980; Thorpe, 1992). Categories of sexual orientation have been socially constructed throughout time (Focault, 1980; Thorpe, 1992). For example, in ancient Greece no terms for homosexual, heterosexual, or bisexual existed, the most important aspect of sexuality being whether a person engaged in the active or passive role (Dover, 1989; Thorpe, 1992). The passive role was for inferiors defined in reference to their society, such as women, slaves, or male youths not yet citizens (Dover, 1989). A citizen could penetrate any non-citizen he pleased, but a citizen could not take the passive role and be penetrated orally or otherwise (Thorpe, 1992). Clearly this is a very different social definition relative to that of our modern industrial era.

In more modern times 10-20\% of South Seas cultures approve of homoerotic contact between older and younger individuals (Herdt, 1988). For example, among the Sambia of highland Papua New Guinea, boys age 7-10 are ritually inducted into homoerotic relationships with older males (Herdt, 1988). Even after 10 or so years in these homoerotic relationships the younger males move on to heteroerotic relationships, as culturally prescribed, without any apparent impact on sexual functioning (Bhugra et al, 2010; Stoller \& Herdt, 1985). In ancient Greek and Roman societies homoerotic relationships between men and young males were considered acceptable, so long as the man was active and the younger male passive (Thorp, 1992). These homoerotic relationships facilitated by the particular social/cultural construction of sexuality aid in alliance formation between younger males and more established older men of the society, highlighting the alliance formation function of homoerotic behavior (Muscarella, 2000). In such instances the homoerotic dimension is activated, and those having a non-zero motivation for it (apparently the case in most or all individuals based on South Seas and historical examples) actively engage in such behavior, and yet shift to heteroerotic relationships later on involving activation of that dimension.

The social construction of sexual orientation can then strongly guide how sexuality is expressed. In modern industrial society this takes the form of establishing a permanent identity as opposed to behavior itself. Jeffrey Weeks (1985) indicates a distinction must be made "between homosexual behavior, which is universal, and a homosexual identity, which is historically specific." Historically (and in some current South Seas cultures) the focus has been on behavior and not a permanent identity (Ford \& Beach, 1951; Herdt, 1998; Thorpe, 1992; Weeks, 1985; Williams, 1936). In modern industrial society a shift to homoerotic and heteroerotic behavior as a permanent identity has occurred, reinforcing a dichotomous perspective. The reasons for this shift are not clear but one potential candidate might be defensive compensation for a lack of identity arising from industrialization.

With industrialization people primarily serve to enhance productivity and economic growth, and as such are secondary, a notion that would have been inconceivable in ancient Greek or Roman times or in more modern South Seas cultures. Interestingly, as modern industrial society encroaches on regions such as Papua New Guinea, sexual practices are shifting away from traditional approaches to ones more in line with Western ideology (Knauft, 2003). Identities such as "homosexual" can compensate for the secondary status of people in an industrial form of social organization. They provide a powerful in-group status and sense of belonging based on shared preferences, interests, beliefs, customs, and behavioral styles (Reynolds et al, 2000). Such identities can help compensate for another aspect of industrialization, namely the isolation that many people experience as the family structure present in hunting-gathering and agricultural forms of social organization deteriorates.

Transformed into an identity, homoerotic and heteroerotic behavior become more than mere acts that can shift with circumstances; they characterize a person. A "homosexual" identity is typically adopted when a person has a higher homoerotic motivation and lower heteroerotic motivation, and a "heterosexual" identity when homoerotic and 
heteroerotic motivation levels are reversed. A bisexual identity tends to occur when both homoerotic and heteroerotic motivations are more nearly equal. However, based on dichotomous homosexual and heterosexual identities, a bisexual identity is more difficult to process (Fahs, 2009; Gammon \& Isgro, 2006).

With "homosexuality" and "heterosexuality" as identities, erotic fantasy and actual physical behavior inconsistent with the given orientation are difficult to understand and accept, unless a person identifies with being bisexual. Homoerotic and heteroerotic behavior adaptive in a given circumstance, but inconsistent with sexual orientation identity, is likely to be suppressed. Hence, the prominence of homosexual and heterosexual identities then likely obscures and over-rides the natural organization of sexual behavior into homoerotic and heteroerotic dimensions. Consequently, the less dominant dimension is more likely to be deactivated.

\section{Conclusion}

Theories of sexual orientation proposed to date are flawed, or highly limited in applicability only accounting for a minor portion of the variance, such as for a small subset of male homosexuality. A key reason for this occurrence is that they assume to varying degrees that "homosexuality" and "heterosexuality" correspond to real entities. In contrast, the model proposed here views them as only approximate descriptions of natural occurrences, in line with social constructionist views. Four interconnected components, consisting of dimensions of sexual orientation, activation/deactivation of these dimensions, erotic fantasy, and social construction, appear capable of explaining both male and female human sexual orientation. Consistent with other natural phenomena, sexual orientation is organized dimensionally. Regarding the number of dimensions, the inability of a single dimension to account for many aspects of sexual orientation necessitates a two-dimensional model. The presence of separate homoerotic and heteroerotic dimensions adequately accounts for bisexuality, asexuality, and why some people preferentially express one type of sexual orientation. "Heterosexuality" occurs when heteroerotic motivation > homoerotic motivation, and "homosexuality" when the reverse profile occurs. "Homosexuality" is less common because it can only indirectly facilitate reproduction so integral to natural selection, whereas heteroerotic behavior directly promotes reproduction. Consequently, for most people there is a higher level of motivation on the heteroerotic dimension.

The notion of homoerotic and heteroerotic dimension activation represents a novel contribution to our understanding of sexual orientation. The dominant dimension is typically activated, but the less dominant dimension can be activated by specific circumstances. Homoerotic and heteroerotic dimensions can also be deactivated by occurrences. Dimension activation/deactivation provides at least a partial explanation for the increased prevalence of homoerotic behavior in same-sex settings, and how sexual abuse influences the expression of sexual orientation. Activation/deactivation of sexual orientation dimensions aligns with how the brain is organized largely on the basis of activation and deactivation. Erotic fantasy can activate homoerotic and heteroerotic dimensions, although its key role is providing an entire layer to sexual orientation beyond actual behavior, consistent with how the evolution of human intelligence amplifies psychological states. Social construction of sexual orientation influences the activation/deactivation of these dimensions, with the modern industrial era and sexual orientation identities favoring deactivation of the less dominant dimension.

Many components of the model require testing such as how well separate homoerotic and heteroerotic dimensions apply to different populations. Any such testing should not confuse descriptors, such as sexual attraction, sexual behavior, sexual fantasies, lifestyle preference, and self-identification, with actual dimensions. It is suggested that dimensions be kept to an absolute minimum to avoid the problems encountered with the model by Klein (1993), where the introduction of several possible "dimensions" led to the invariable suggestion that several others were missed. Incorporation of all viable "dimensions" will produce a model that is impossible to apply without sophisticated mathematical models and computing power. In addition, what appears to apply based on animal research in natural contexts is homoerotic and heteroerotic dimensions. Predictions related to the notion of varying circumstances activating sexual orientation dimensions are testable, such as how same-sex settings and erotic fantasy can activate the homoerotic dimension even if less dominant. The related notion of dimension deactivation can also be researched, as with the proposal that adverse experiences and inconsistent sexual orientation identity can deactivate dimensions. Neuroimaging studies can explore brain changes associated with activation/deactivation, a line of investigation that will help identify the neural basis of sexual orientation.

The proposed model fully explains the Darwinian or evolutionary paradox of how "homosexual" behavior could ever evolve given that it does not directly facilitate reproduction - With the capacity for both homoerotic and heteroerotic behavior, and the benefits of the former (alliance formation, tension reduction, and reconciliation) even for enhancing reproductive opportunities, the presence of "homosexual" behavior is at all not inconsistent with reproduction. Both homoerotic and heteroerotic behavior can be expressed to facilitate alliance formation and other functions, without interfering with one another given that they operate on separate dimensions. It is only when "homosexuality" becomes an identity excluding reproductive behavior that the paradox arises. For example, how can a "homosexual" person engage in 
intercourse with an other-sex person? If so, then the person can no longer be homosexual, but based on attraction, fantasy, and action patterns the person cannot be heterosexual or bisexual. These confusing scenarios are eliminated with distinct heteroerotic and homoerotic dimensions, with people having varying motivations on both that can shift over time in response to circumstances and activation/deactivation patterns. An additional benefit of the model is that it has the potential to reduce discrimination based on sexual orientation, derived from the understanding that we all possess the capacity for both homoerotic and heteroerotic behavior that can be activated by specific circumstances - If we all possess both capacities there is reduced likelihood of negative ingroup/outgroup distinctions arising from sexual orientation, and the discrimination that can follow from such distinctions. The comprehensive model of human sexual orientation provided here then has very practical implications, beyond just improving our understanding.

\section{References}

Akers, J., \& Conway, C. (1979). Female homosexual behavior. Macaca mulatta. Archives of Sexual Behavior, 8, 63-80. http://dx.doi.org/10.1007/BF01541214

Bagemihl, B. (1999). Biological Exuberance: Animal Homosexuality And Natural Diversity. New York: St. Martin's Press.

Bailey, J. M., \& Pillard, R. C. (1991). A genetic study of male sexual orientation. Archives of General Psychiatry, 48, 1089-1094. http://dx.doi.org/10.1001/archpsyc.1991.01810360053008

Barish, D. P. (1982). Sociobiology and behavior. New York: Elsevier.

Baron, M. (1993). Genetic linkage and male homosexual orientation. BMJ, 307, 338-347. http://dx.doi.org/10.1136/bmj.307.6900.337

Bearman, P. S., \& Bruckner, H. (2002). Opposite-sex twins and adolescent same-sex attraction. American Journal of Sociology, 107(5), 1179-1205. http://dx.doi.org/10.1086/341906

Bell, A. P., Weinberg, M. S., \& Hammersmith, S. K. (1981). Sexual preference: Its development in men and women. Bloomington: Indiana University.

Bem, D. J. (1996). Exotic becomes erotic: A developmental theory of sexual orientation. Psychological Review, 103(2), 320-335. http://dx.doi.org/10.1037/0033-295X.103.2.320

Bemporad, J. R. (1991). Dementia praecox as a failure of neoteny. Theoretical Medicine, 12, 45-51. http://dx.doi.org/10.1007/BF02134777

Behrman, K. D., \& Kirpatrick, M. (2011). Species range expansion by beneficial mutations. Journal of Evolutionary Biology, 24(3), 665-675. http://dx.doi.org/10.1111/j.1420-9101.2010.02195.x

Bhugra, D., McMullen, I., \& Popelyuk, D. (2010). Paraphilias across cultures: Contexts and controversies. The Journal of Sex Research, 47(2-3), 242-262. http://dx.doi.org/10.1080/00224491003699833

Bieber, I., Dain, H. J., Dince, P. R., Drelich, M. C., Grand, H. G., Gundlach, R. H. et al. (1962). Homosexuality: A Psychoanalytic Study of Male Homosexuals. New York: Basic Books. http://dx.doi.org/10.1037/11179-000

Blackwood, E. (1985). Breaking the mirror: the construction of lesbianism and the anthropological discourse on homosexuality, 11(3-4), 1-17.

Blanchard, R. (2008). Review and theory of handedness, birth order, and homosexuality in men. Laterality, 13(1), 51-70. http://dx.doi.org/10.1080/13576500701710432

Boelkins, R. C., \& Wilson, R. P. (1972). Intergroup social dynamics of the Cayo Santiago rhesus (macaca mulatta) with special reference to changes in group membership by males. Primates, 13, 125-140. http://dx.doi.org/10.1007/BF01840875

Boswell, J. (1980). Christianity, social tolerance, and homosexuality. Chicago: University of Chicago Press. 
Boswell, J. (1994). Same-sex unions in premodern europe. New York: Villard Books.

Bowins, B. E. (2004). Psychological defense mechanisms: A new perspective. American Journal of Psychoanalysis, 64, 1-26. http://dx.doi.org/10.1023/B:TAJP.0000017989.72521.26

Braaten, L. J., \& Darling C. D. (1965). Overt and covert homosexual problems among male college students. Genetic Psychology Monographs, 71, 302-303. http://dx.doi.org/10.1093/aob/mct176

Bramblett, J. R., \& Darling, C. A. (1997). "Sexual contacts: Experiences, thoughts, and fantasies of adult male survivors of child sexual abuse. Journal of Sex \& Marital Therapy, 23(4), 313, 23-36.

Brousseau, L., Bonal, D., Cigna, J., \& Scotti, I. (2013). Highly local environmental variability promotes intrapopulation divergence of quantitative traits: an example from tropical rain forest trees. Annals of Botany, 112(6), 1169-1179.

Brown, D. G. (1963). Homosexuality and family dynamics. Bulletin of the Menninger Clinic, 27(5), 28-43.

Byne, W., Tobet, S., \& Mattiace, L. A. (2001). The interstitial nuclei of the anterior hypothalamus: An investigation of variance with sex, sexual orientation, and HIV status. Hormones and Behavior, 40(2), 86-92. http://dx.doi.org/10.1006/hbeh.2001.1680

Calam, R., Horne, L., Glasgow, D., \& Cox, A. (1998). Psychological disturbance and child sexual abuse: A follow-up study. Child Abuse \& Neglect, 22(9), 901-913. http://dx.doi.org/10.1016/S0145-2134(98)00068-4

Cantarella, E. (1992). Bisexuality in the ancient world. New Haven: Yale University Press.

Ciani, A. C., Cermelli, P., \& Zanzotto, G. (2008). Sexually antagonistic selection in human male homosexuality. Plos One, 3(6), e2282.

Chevin, L. M., \& Lande, R. Evolution of discrete phenotypes from continuous norms of reaction. American Naturalist, 182(1), 13-27.

Crepault, C., \& Coulture, M. (1980). Men's erotic fantasies. Archives of Sexual Behavior, 9(6), 565-581. http://dx.doi.org/10.1007/BF01542159

Darwin, C. (1858). The Origin of Species. London:

Davies, N. B. (1991). Mating systems. In J.R. Krebs and N.B. Davies (Eds.), Behavioural ecology: An evolutionary approach (Third Edition), Boston: Blackwell Scientific Publications, 263-294.

Denniston, R. H. (1980). Ambisexuality in animals. In J. Marmor (Ed.), Homosexual behavior: A modern reappraisal New York: Basic Books, 25-40.

deWaal, F. (1982). Chimpanzee politics: Power and sex among apes. New York: Harper \& Row.

deWaal, F., \& Lansing, F. (1997). Bonobo: The forgotten ape. Berkeley: University of California Press.

Diamond, L. M. (2006). The evolution of plasticity in female-female desire. Journal of Psychology \& Human Sexuality, 18(4), 245-274. http://dx.doi.org/10.1300/J056v18n04_01

Dickemann, M. (1995). Wilson panchreston: the inclusive fitness hypothesis of sociobiology re-examined. Journal of Homosexuality, 28(1-2), 147-183. http://dx.doi.org/10.1300/J082v28n01_09

Dorner, (1980). Sexual differentiation of the brain. Vitamins And Minerals, 38, 325-381.

Dover, K. J. (1989). Greek homosexuality. Cambridge: Harvard University Press.

Dunkle, S. W. (1991). Head damage from mating attempts in dragonflies. Entomological News, 102(1), 37-41.

Easpaig, B. R., Fryer, D. M., Linn, S. E., \& Humphrey, R. H. (2014). A queer-theoretical approach to community health psychology. Journal of Health Psychology, 19(1), 117-125. http://dx.doi.org/10.1177/1359105313500259 
Edwards, A. A., \& Todd, J. D. (1991). Homosexual behaviour in wild white-handed gibbons (hylobates lar). Primates, 32(2), 231-236. http://dx.doi.org/10.1007/BF02381180

Ellis, B. J., \& Simmons, D. (1990). Sex differences in sexual fantasy: An evolutionary approach. Journal of Sex Research, 27, 527-555. http://dx.doi.org/10.1080/00224499009551579

Eschoffier, J. (1998). American Homo: Community And Perversity. Berkely: University Of California Press.

Estes, L. S., \& Tidwell, R. (2002). Sexually abused children's behaviors: Impact of gender and mother's experience of intra- and extra-familial sexual abuse. Family Practice, 19(1), 36-44. http://dx.doi.org/10.1093/fampra/19.1.36

Evans, R. B. (1969). Childhood parental relationships of homosexual men. Journal of Counseling and Clinical Psychology, 33, 129-133. http://dx.doi.org/10.1037/h0027186

Fairbanks, L. A., McGuire, M. T., \& Kerber, W. (1977). Sex and aggression during rhesus monkey group formation. Aggression and Behavior, 3, 241-249. http://dx.doi.org/10.1002/1098-2337(1977)3:3<241::aid-ab2480030305>3.0.co;2-1

Fahs, B. (2009). Compulsory bisexuality?: The challenges of modern sexual fluidity. Journal of Bisexuality, 9, 431-449. http://dx.doi.org/10.1080/15299710903316661

Focault, M. (1980). The History of Sexuality. New York: Vintage Books.

Ford, C. S., \& Beach, F. A. (1951). Patterns of sexual behavior. New York: Harper.

Friedman, R. C. (1988). Male Homosexuality: A Contemporary Psychoanalytic Perspective. New Haven: Yale University Press.

Freud, S. (1905/1962). Three essays on the theory of sexuality, trans. James Strachey. New York: Basic Books.

Freud, S. (1908/1962). Creative writers and daydreaming. In J. Strachy (Ed.). The Standard Edition of the Complete Psychological Works of Sigmund Freud, London: Hogarth, 9, 142-152.

Gammon, M. A., \& Isgro, K. L. (2006). Troubling the canon: bisexuality and queer theory. Journal of Homosexuality, 52(1-2), 159-184. http://dx.doi.org/10.1300/J082v52n01_07

Goodall, J. (1965). Chimpanzees of the gombe stream reserve. In I. DeVore (Ed.), Primate Behavior: Field studies of monkeys and apes, New York: Holt, Rinehart, \& Winston, 425-473.

Greenberg, D. F. (1988). The construction of homosexuality. Chicago: University of Chicago Press.

Hall, D. K., Mathews, F., \& Pearce, J. (1998). Factors associated with sexual behavior in young sexually abused children. Child Abuse \& Neglect, 22(10), 1045-1063. http://dx.doi.org/10.1016/S0145-2134(98)00078-7

Hamer, D. H., Hu, S., Magnuson, V. L., Hu, N., \& Pattatucci, A. M. (1993). A linkage between dna markers on the X-chromosome and male sexual orientation. Science, 261, 321-327. http://dx.doi.org/10.1126/science.8332896

Hanby, J. P., Robertson, L.T., \& Phoenix, C. H. (1971). The sexual behavior of a confined troop of Japanese macaques. Folia Primatologica, 16, 123-143. http://dx.doi.org/10.1159/000155394

Harrison, M. A., Hughes, S. M., Burch, R. L., \& Gallup, G. G. (2008). The impact of prior heterosexual experiences on homosexuality in women. Evolutionary Psychology, 6(2), 316-327.

Haumann, G. (1995). Homosexuality, biology, and ideology. Journal of Homosexuality, 28(1-2), 57-77. http://dx.doi.org/10.1300/J082v28n01_04

Herdt, G. H. (1988). Cross-cultural forms of homosexuality and the concept 'gay.' Psychiatric Annals, 18(1), 37-39. http://dx.doi.org/10.3928/0048-5713-19880101-11

Herdt, G. (1998). Same Sex, Different Cultures. New York:West View Press.

Hinsch, B. (1990). Passions of the cut sleeve: The male homosexual tradition in china. Berkeley: University of California Press.

Hotte, J. P., \& Rafman, S. (1992). The specific effects of incest on prepubertal girls from dysfunctional families. Child Abuse \& Neglect, 16(2), 273-283. http://dx.doi.org/10.1016/0145-2134(92)90034-O 
Hutchinson, G. E. (1959). A speculative consideration of certain forms of sexual selection in men. American Nature, 93, 81-91. http://dx.doi.org/10.1086/282059

Iasenza, S. (2010). What is queer about sex? Expanding sexual frames in theory and practice. Family Processes, 49(3), 291-308. http://dx.doi.org/10.1111/j.1545-5300.2010.01324.x

Ioannidis, J. (2005). Why most published research findings are false. PLoS Med, 2(8), 24. http://dx.doi.org/10.1371/journal.pmed.0020124

Kano, T. (1992). The last ape: Pygmy chimpanzee behavior and ecology. Standford, CA: Stanford University Press.

Kauth, M. (2000). True Nature: A Theory of Sexual Attraction. New York: Springer. http://dx.doi.org/10.1007/978-1-4615-4301-5

Kennedy, M. (2010). Rural men, sexual identity and community. Journal of Homosexuality, 57(8), 1051-1091. http://dx.doi.org/10.1080/00918369.2010.507421

Kinsey, A. C., Pomeroy, W. B., \& Martin, C. E. (1948). Sexual Behavior in the human male. Philadelphia: W.B. Saunders.

Kinsey, A. C., Pomeroy, W. B., Martin, C. E., \& Gebhard, P. H. (1953). Sexual Behavior in the human female. Philadelphia: W.B. Saunders.

Kirsch, J. A., \& Rodman, J. E. (1982). Selection and sexuality: The Darwinian view of homosexuality. In W. Paul \& J.D. Weinrich (Eds.), Homosexuality: social, psychological, and biological issues. Beverly Hills: Sage Publications, 183-195.

Klein, F. (1993). The Bisexual Option. New York: Haworth Press.

Klein, F., Sepekoff, B., \& Wolf, T. J. (1985). Sexual orientation: A multi-variable dynamic process. Journal of Homosexuality, 11, 35-49. http://dx.doi.org/10.1300/J082v11n01_04

Knauft, B. M. (2003). What ever happened to ritualized homosexuality? Modern sexual subjects in Melanesia and elsewhere, 14, 137-159.

Kuhle, B. (2013). Born both ways: The alloparenting hypothesis for sexual fluidity in women. Evolutionary Psychology, 11(2), 304-323.

Larson, P. C. (1981). Sexual identity and self-concept. Journal of Homosexuality, 7(1), 15-32. http://dx.doi.org/10.1300/J082v07n01_03

Lasco, M. S., Jordan, T. J., Edgar, M. A., Petito, C. K., \& Byne, W. (2002). A lack of dimorphism of sex or sexual orientation in the human anterior commissure. Brain Research, 936, 95-105. http://dx.doi.org/10.1016/S0006-8993(02)02590-8

Leitenberg, H., \& Henning, K. (1995). Sexual fantasy. Psychological Bulletin, 117(3), 469-496. http://dx.doi.org/10.1037/0033-2909.117.3.469

Lentz, S. L., \& Zeiss, A. M. (1983). Fantasy and sexual arousal in college women: An empirical investigation. Imagination, Cognition and Personality, 3, 185-202. http://dx.doi.org/10.2190/XV8Q-9NV0-MVKX-8G9X

LeVay, S. (1991). A difference in hypothalamic structure between heterosexual and homosexual men. Science, 253(30), 1034-1037. http://dx.doi.org/10.1126/science.1887219

LeVay (2012). Gay, Straight, and the Reason Why: The Science Of Sexual Orientation. New York: Oxford University Press.

MacIntyre, F., \& Estep, K.W. (1993). Sperm competition and the persistence of genes for male homosexuality. Biosystems, 31, 223-233. http://dx.doi.org/10.1016/0303-2647(93)90051-D

Mackey, W. C. (1990). Adult-male/juvenile association as a species-characteristic human trait: A comparative field approach. In J. R. Feierman (Ed), Pedophilia: biosocial dimensions. New York: Springer-Verlag, 299-323. http://dx.doi.org/10.1007/978-1-4613-9682-6_12

Maeve, M. K. (1999). The social construction of love and sexuality in a women's prison. ANS Advanced Nursing Science, 21(3), 46-65. http://dx.doi.org/10.1097/00012272-199903000-00007

Mahurin, R. K., Velligan, D. I., \& Miller, A. L. (1998). Executive-frontal lobe cognitive dysfunction in schizophrenia: A symptom subtype analysis. Psychiatry Research, 79,139-149. http://dx.doi.org/10.1016/S0165-1781(98)00031-6

McKenzie, S. (2010). Genders and sexualities in individuation: theoretical and clinical explorations. Journal of Analytical Psychology, 55(1), 91-111. http://dx.doi.org/10.1111/j.1468-5922.2009.01826.x 
McLaughlin, K. A., Hatzenbuehler, M. L., Xuan, Z., \& Conron, K. J. (2012). Disproportionate exposure to early-life adversity and sexual orientation disparities in psychiatric morbidity. Child Abuse \& Neglect, 36(9), 645-655. http://dx.doi.org/10.1016/j.chiabu.2012.07.004

Mehlman, P. T., \& Chapais, B. (1988). Differential effects of kinship, dominance, and the mating season on female allogrooming in a captive group of macaca fuscata. Primates, 29(2), 195-217. http://dx.doi.org/10.1007/BF02381122

Middleton, W. (2013). Ongoing incestuous abuse during adulthood. Journal of Trauma \& Dissociation, 14(3), 251-272. http://dx.doi.org/10.1080/15299732.2012.736932

Mitchell, G. (1979). Behavioral sex differences in nonhuman primates. New York: Van Nostrand Reinhold Company.

Money, J. (1988). Gay, straight, and in-between: The sexology of erotic orientation. New York: Oxford University Press.

Mori, U. (1979). Development of sociability and social status. In M. Kawai (Ed.), Ecological and sociological studies of gelada baboons, Tokyo: Kodansha-Karger, 125-154.

Murray, J. B. (2000). Psychological profile of pedophiles and child molesters. The Journal of Psychology, 134(2), 211-224. http://dx.doi.org/10.1080/00223980009600863

Muscarella, F. (1999). The homoerotic behavior that never evolved. Journal of Homosexuality, 37(3), 1-18. http://dx.doi.org/10.1300/J082v37n03_01

Muscarella, F. (2000). The evolution of homoerotic behavior in humans. Journal of Homosexuality, 40(1), 51-77. http://dx.doi.org/10.1300/J082v40n01_03

Mustanski, B. S., Dupree, M. G., Niervergelt, C. M., Bocklandt, S., Schork, N. J., \& Hamer, D. H. (2005). A genomewide scan of male sexual orientation. Human Genetics, 116(4), 272-278. http://dx.doi.org/10.1007/s00439-004-1241-4

O’Connor, P. J. (1964). Aetiological factors in homosexuality as seen in royal air force psychiatric practice. British Journal of Psychiatry, 110, 384-385. http://dx.doi.org/10.1192/bjp.110.466.381

Parish, A. R. (1994). Sex and food control in the "uncommon chimpanzee": How bonobo females overcome a phylogenetic legacy of male dominance. Ethology and Sociobiology, 15, 157-194. http://dx.doi.org/10.1016/0162-3095(94)90038-8

Paul, T., Schiffer, B., Zwarg, T., Kruger, T. H., Karama, S., Schedlowski, N., Forsting, M., \& Gizewski, E. R. (2008). Human Brain Mapping, 29(6), 726-735.

Pedersen, W., \& Kristiansen, H. W. (2008). Homosexual experience, desire and identity among young adults. Journal of Homosexuality, 54(1-2), 68-102. http://dx.doi.org/10.1002/hbm.20435

Poiani, A. (2010). Animal homosexuality: A biosocial approach. Cambridge: Cambridge University Press. http://dx.doi.org/10.1017/CBO9780511762192

Priebe, G., \& Svedin, C. G. (2013). Operationalization of three dimensions of sexual orientation in a national survey of late adolescents. Journal of Sexual Research, 50(8), 727-738. http://dx.doi.org/10.1080/00224499.2012.713147

Pusey, A. E., \& Packer, C. (1987). Dispersal and philopatry. In B.B Smuts, D.L. Cheney, R. M. Seyfarth, R. W. Wrangham, \& Struhsaker, T. T. (Eds.), Primate societies Chicago: Chicago University Press, 250-266.

Putnam, F. W. (2003). Ten-year research update review: Child sexual abuse. Journal of the American Academy of Child and Adolescent Psychiatry, 42(3), 269-278. http://dx.doi.org/10.1097/00004583-200303000-00006

Rahman, Q. (2005). The neurodevelopment of sexual orientation. Neuroscience and Biobehavioral Reviews, 29(7), 1057-1066. http://dx.doi.org/10.1016/j.neubiorev.2005.03.002

Reynolds, K., Turner, J., \& Haslam, S. (2000). When are we better than them and they worse than us? A closer look at social discrimination in positive and negative domains. Journal of Personality and Social Psychology, 78(1), 64-80. http://dx.doi.org/10.1037/0022-3514.78.1.64

Rice, G., Anderson, C., Risch, N., \& Ebers, G. (1999). Male homosexuality: Absence of linkage to microsatellite markers at xq28. Science, 284, 666-678. http://dx.doi.org/10.1126/science.284.5414.665

Ross, A. (1973). Celtic and northern art. In P. Rawson (Ed.), Primitive erotic art, New York: G.P. Putman \& Sons, 77-106.

Savage-Rumbaugh, E. S., \& Wilkerson, B. J. (1978). Socio-sexual behavior in pan paniscus and pan troglodytes: A 
comparative study. Journal of Human Evolution, 7, 327-344. http://dx.doi.org/10.1016/S0047-2484(78)80074-8

Shively, M. G., \& De Cecco, J. P. (1977). Components of sexual identity. Journal of Homosexuality, 3(1), 41-48. http://dx.doi.org/10.1300/J082v03n01_04

Singer, B. (1985). A comparison of evolutionary and environmental theories of erotic response: Part II. Empirical arenas. Journal of Sex Research, 21, 345-374. http://dx.doi.org/10.1080/00224498509551275

Small, M. F. (1993). Female choices: Sexual behavior of female primates. Ithaca, NY: Cornell University Press.

Small, M. F. (1995). What's love got to do with it? The evolution of human mating. New York: Doubleday.

Smuts, B. B. \& Watanabe, J. M. (1990). Social relationships and ritualized greetings in adult male baboons (papio cynocephalus Anubis). International Journal of Primatology, 11, 147-172. http://dx.doi.org/10.1007/BF02192786

Stoller, R. J., \& Herdt, G. H. (1985). Theories of origins of male homosexuality. Archives of General Psychiatry, 42, 399-404. http://dx.doi.org/10.1001/archpsyc.1985.01790270089010

Storms, M. D. (1980). Theories of sexual orientation. Journal of Personality \& Social Psychology, $38(5), 783-792$. http://dx.doi.org/10.1037/0022-3514.38.5.783

Swaab, D. F., \& Fliess, E. (1985). A sexual dimorphic nucleus in the human brain. Science, 228, 1112-1114. http://dx.doi.org/10.1126/science.3992248

Taub, D. M. (1990). The functions of primate paternalism: A cross-species review. In J.R. Feierman (Ed.), Pedophilia: biosocial dimensions, New York: Springer-Verlag, 338-377. http://dx.doi.org/10.1007/978-1-4613-9682-6_14

Thorp, J. (1992). Review article/discussion: The social construction of homosexuality. Phoenix, 46(1), 54-65. http://dx.doi.org/10.2307/1088774

Van der Dennen, J. M. (1995). The origins of war: The evolution of male-coalitional reproductive strategy. Groningen, Netherlands: Origin Press.

Vasey, P. L. (1995). Homosexual behavior in primates: A review of evidence and theory. International, Journal of Primatology, 16(2), 173-203. http://dx.doi.org/10.1007/BF02735477

Weeks, J. (1985). Sexuality And Its Discontents. London: Routledge and Kegan Paul. http://dx.doi.org/10.4324/9780203407462

Weinrich, J. D. (1980). Homosexual behavior in animals: A new review of observations from the wild and their relationship to human sexuality. In R. Forleo, \& W. Pasini (Eds.), Medical sexology: The third international congress, Littleton, MA: PSG Publishing, 288-295.

Weinrich, J. D. (1982). Is homosexuality biologically natural? In W. Paul \& J.D. Weinrich (Eds.), Homosexuality: Social, psychological, and biological issues, Beverly Hills: Sage Publications, 197-208.

Weinrich, J. D., Snyder, P.J., Pillard, R.C., Grant, I., Jacobson, D. L., Robinson, S. R., \& McCutchan, J. A. (1993). A factor analysis of the klein sexual orientation grid in two disparate samples. Archives of Sexual Behavior, 22, 157-168. http://dx.doi.org/10.1007/BF01542364

West, D. J. (1977). Homosexuality re-examined. London: Gerald Duckwort \& Co. Ltd.

Whitehead, N. E. (2007). An antiboy antibody? Re-examination of the maternal immune hypothesis. Journal of Biosocial Science, 39(6), 905-921. http://dx.doi.org/10.1017/S0021932007001903

Williams, F. E. (1936). Papuans Of The Trans-Fly. London: Oxford University Press.

Wilson, E.O. (1978). On human nature. Cambridge, MA: Harvard University Press.

Wrangham, R.W. (1986). Ecology and social relationships in two species of chimpanzee. In D.I. Rubenstein, \& R.W. Wrangham (Eds), Ecological aspects of social evolution: Birds and mammals. Princeton, New Jersey: Princeton University Press.

Yamagiwa, J. (1987). Intra and inter group interactions of an all-male group of virunga mountain gorillas (gorilla gorilla beringei). Primates, 28(1), 1-30. http://dx.doi.org/10.1007/BF02382180

\section{(cc) $\mathrm{BY}$}

This work is licensed under a Creative Commons Attribution 3.0 License. 